Original Research Paper

\title{
Diversitas Kultivar tanaman Durian (Durio zubethinus Murr.) Ditinjau dari Karakter Morfologi
}

\author{
Najira $^{1^{*}}$, Eka Selviyanti ${ }^{1}$, Yosia Br.Tobing ${ }^{1}$, Kasmawati $^{1}$, Rosalina Sianturi $^{1}$, Adi Bejo Suwardi ${ }^{1}$ \\ ${ }^{1}$ Program Studi Pendidikan Biologi, Fakultas Keguruan dan ilmu pendidikan, Universitas Samudra, Jln. Meurandeh, \\ Kecamatan Langsa Lama, Kota Langsa, Provinsi Aceh, Indonesia.
}

\author{
Riwayat artikel \\ Received : 04 Mei 2020 \\ Revised : 10 Mei 2020 \\ Accepted : 12 Mei 2020 \\ Published : 19 Mei 2020 \\ *Corresponding Author: \\ Najira \\ Jurusan Pendidikan Biologi \\ FKIP \\ Universitas Samudra, Kota \\ Langsa , Indonesia; \\ Email: najirapv10@gmail.com
}

\begin{abstract}
Abstrak: Durian (Durio zubethinus Murr.) Merupakan salah satu jenis buah tropis dari famili Bombacaceae yang memiliki nilai ekonomis yang tinggi. Tujuan penelitian untuk mendapatkan keragaman karakteristik dan tingkat kemiripan tanaman durian di desa Sukajadi Makmur, Kota Langsa, Provinsi Aceh. Penelitian ini dilaksanakan pada bulan September 2019 - Februari 2020 Penelitian dilakukan dengan metode eksplorasi yaitu penelusuran keberadaan tanaman durian di wilayah penelitian dan wawancara. Hasil karakterisasi morfologi untuk bentuk pohon durian (Jorong, Bulat, dan Lonjong), Permukaan batang (kasar dan halus), Bentuk daun (lonjong, bulat panjang dan bulat telur) dan bentuk buah (Bulat, membulat, bulat telur, lonjong dan bulat panjang). Perlu dilakukan penelitian secara khusus yang mengarahkan pada eksplorasi karakteristik sifat morfologi dan molekuler serta kualitas buah durian di Provinsi Aceh.
\end{abstract}

Kata Kunci: Diversitas; Kultivar; Karakter morfologi; Durian; Desa Sukajadi.

Abstract: Durian (Durio zubethinus Murr.) Is a type of tropical fruit from the Bombacaceae family that has high economic value. The purpose of this research is to get the facts and the similarity of durian plants in the village of Sukajadi Makmur, Langsa City, Aceh Povince. This research was conducted in September 2019 - February 2020. The Research was conducted with an exploratory method, namely the search for the existence of durian plants in the study area and interviews. Results of the characterization of Durian plants in the form of durian trees (Jorong, round, and oval), stem surface (rough and smooth), leaf shape (round, rounded, ovoid, oval, and elliptical). Sprecific research needs to be conducted that leads to the exploration of morphological and molecular characteristics and the quality of durian in Aceh Province.

Keywords: Diversity; Cultivars; Morphological Character; Durian; Sukajadi Village.

\section{Pendahuluan}

Provinsi Aceh merupakan salah satu daerah dengan keanekaragaman jenis tumbuhan buah lokal yang tinggi (Suwardi et al., 2019a; Navia et al., 2019; Suwardi et al., 2020a). Tumbuhan buah tersebut ditemukan tumbuh liar di hutan dan sebagian diantaranya telah dibudidayakan. Tumbuhan buah liar memiliki cita rasa yang khas dan tidak jauh berbeda dengan tumbuhan buah budidaya (Suwardi et al., 2019b). Berbagai jenis buah-buahan telah dimanfaatkan oleh masyarakat sebagai sumber nutrisi (Navia et al., 2017; Suwardi et al., 2020b).

Desa Sukajadi Makmur, Kecamatan Langsa Baro memiliki iklim yang sangat mendukung pertumbuhan pohon durian. Berbagai jenis buah durian yang dihasilkan ternyata memiliki keanekaragaman sifat morfologi, maupun kualitas buahnya, sehingga dapat diperhitungkan masih banyak durian unggulan yang berasal dari Provinsi Aceh. Sampai saat ini belum ada dilakukan penelitian secara khusus yang mengarahkan pada eksplorasi, karakterisasi sifat morfologi dan 
molekuler serta kualitas buah durian dari Provinsi Aceh (Handayani et al., 2017).

Identifikasi Morfologi dipandang kurang tepat dibandingkan molekuler, akan tetapi bukan berarti identifikasi morfologi dan penentuan kualitas buah tidak penting. Analisa hubungan kekerabatan tumbuhan melalui analisis kultivar (seleksi) untuk menentukan kualitas durian yang berperan untuk mengembangkan tanaman, selain itu bidang-bidang terapan misalnya pada upaya pemilihan tanaman (Hadi et al., 2014; Ihsan et al., 2012), Kultur jaringan (Zulkarnain et al., 2013; Lizawati et al., 2012).

Penelitian ini membahas mengenai informasi keragaman tanaman durian dari Provinsi Aceh yang sudah dipilih melalui tahap explorasi, identifikasi dan penentuan kualitas buah durian. Tujuan penelitian ini merupakan untuk mendapatkan keragaman karakteristik dan tingkat kemiripan tanaman durian didesa Sukajadi Makmur, Kota Langsa, Provinsi Aceh.

\section{Bahan dan Metode}

\section{Pengambilan Sampel}

Penelitan ini dilaksanakan pada bulan September 2019 - Februari 2020. Lokasi pengambilan sempel dilakukan di desa Sukajadi Makmur. Alat yang diperlukan seperti kamera, panduan deskripsi tanaman durian, perekam suara, dan alat-alat tulis. Bahan yang diperlukan dalam penelitian ini adalah Tanaman durian yang terdapat di desa Sukajadi Makmur.
Penelitian dilakukan dengan metode eksplorasi yaitu penelusuran keberadaan tanaman durian wilayah penelitian dan wawancara yang bertujuan mengumpulkan data sekunder melalui pertanyaan tersetruktur kepada petani durian setempat. Semua jawaban yang diperoleh dicatat, diolah dan dianalisis secara deskripsi. Identifikasi dan observasi juga dilakukan untuk mendapatkan data primer melalui pengamatan secara langsung pada tanaman durian menggunakan acuan descriptor durian (Biodiversity, 2007).

\section{Hasil dan Pembahasan}

\section{Keragaman Morfologi tanaman Durian di Desa Sukajadi Makmur, Kota Langsa}

Desa Sukajadi Makmur memiliki Intensitas pancaran sinar matahari langsung berkisaran 40-50 persen, iklim pada desa Sukajadi Makmur sendiri bersuhu $26-30^{\circ} \mathrm{c}$ yang sangat sesuai dengan syarat-syarat pertumbuhan tanaman durian. Curah hujan didesa Sukajadi Makmur pun tidak terlalu deras maupun terlalu kering. Letak geografis desa Sukajadi Makmur sendiri mencapat ketinggian 50-1000 meter diatas permukaan laut. Jumlah penduduk desa Sukajadi makmur berjumlah 659 jiwa dengan mata pencarian sebagai petani karet dan berubah profesi menjadi petani durian saat musim panen tiba, dikarenakan buah durian merupakan buah musiman (Leotowicz et al., 2011).

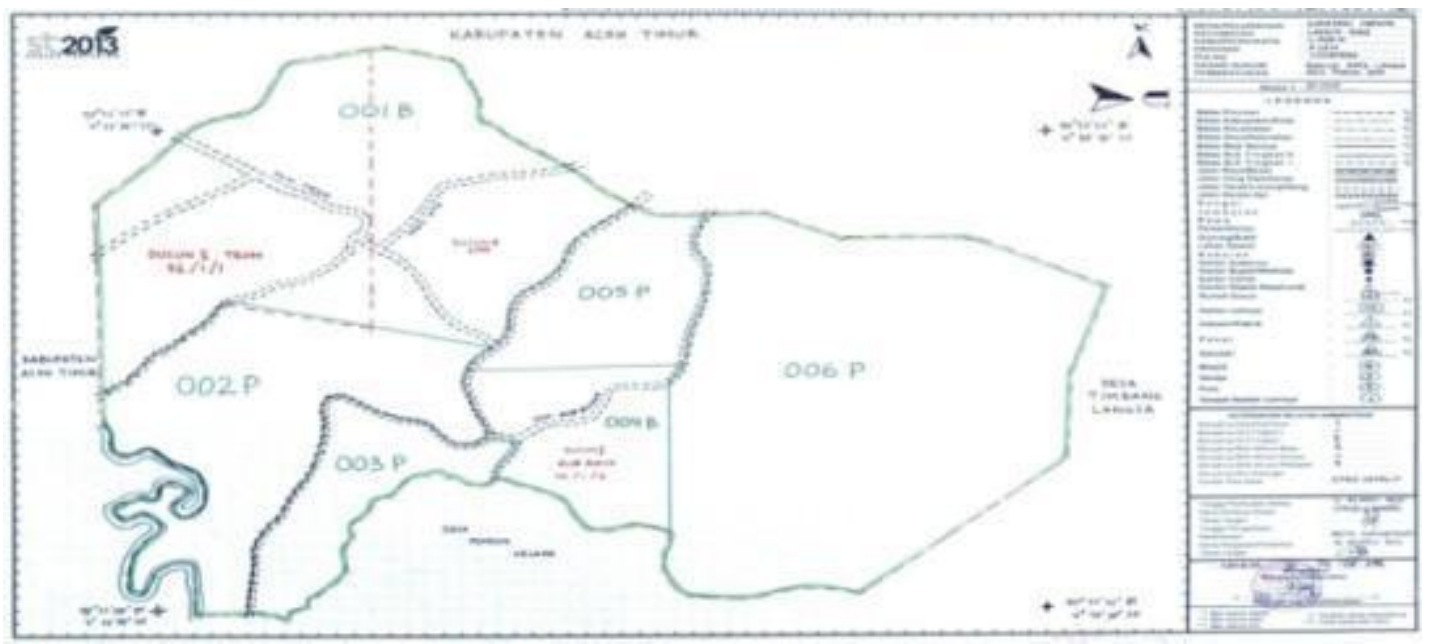

Gambar 1. Peta desa Sukajadi Makmur

Diversitas atau keragaman hayati merupakan salah satu spesies tanaman yang dapat dilihat dari hubungan kekerabatan antara fenotipe dan genotipe dalam spesies tersebut. Tanaman durian didesa Sukajadi Makmur tersebar luas di perkarangan yang masih alami (liar) dan ada juga yang sudah dibudidayakan dengan optimal.

Dari hasil pengamatan di dapatkan bahwa bentuk morfologi batang, daun dan buah durian unggulan dari desa Sukajadi Makmur di Kecamatan Langsa Baro memiliki tingkat keragaman yang tinggi. 


\section{Keanekaragaman Morfologi Batang Durian (Durio zibethinus Murr.) di Desa Sukajadi Makmur.}

Berdasarkan Hasil dari pengamatan karakter morfologi genotipe durian di desa Sukajadi Makmur menunjukkan adanya keragaman pada ciri morfologi batang. Namun, pada pengamatan jenis bahan perbanyakan, permukaan batang, dan pola pertumbuhan batang memiliki persamaan karakteristik dari beberapa fenotipe dan genotipe durian yang diidentifikasi.
Berdasarkan pengamatan terhadap karakter morfologi batang, ditemukan beberapa macam bentuk batang dari genotipe durian yang diidentifikasi yaitu bentuk jorong, bulat, dan lonjong (gambar 1) selain itu, terdapat beberapa genotipe durian yang memiliki akar banir sebagai perkembangan lanjut dari akar sekunder dan berfungsi untuk memperkokoh berdirinya batang tanaman durian. Hasil pengamatan terhadap visual batang durian ditunjukkan pada tabel 1 dan gambar 1 .

Tabel 1. Variasi Morfologi Batang Durian Desa Sukajadi Makmur

\begin{tabular}{|c|c|c|c|c|c|c|}
\hline No & Karakter & Tembaga & Montong & Jantung & Kertas & $\begin{array}{c}\text { Musang } \\
\text { King }\end{array}$ \\
\hline 1. & Tipe Pohon & Bulat Telur & $\begin{array}{c}\text { Bulat Tidak } \\
\text { Sempurna }\end{array}$ & $\begin{array}{c}\text { Bulat Tidak } \\
\text { Sempurna }\end{array}$ & Bulat & Lonjong \\
\hline 2. & Kekuatan Pohon & Sangat Kuat & Kuat & Sangat Kuat & Cukup Kuat & Sangat Kuat \\
\hline 3. & Tinggi Pohon (m) & $13 \mathrm{~m}$ & $8 \mathrm{~m}$ & $25 \mathrm{~m}$ & $22 \mathrm{~m}$ & $15 \mathrm{~m}$ \\
\hline 4. & $\begin{array}{l}\text { Tinggi Pohon Bebas } \\
\text { Cabang }(\mathrm{m})\end{array}$ & $10 \mathrm{~m}$ & $6 \mathrm{~m}$ & $24 \mathrm{~m}$ & $20 \mathrm{~m}$ & $10 \mathrm{~m}$ \\
\hline 5. & Lingkar Batang $(\mathrm{cm})$ & $80 \mathrm{~cm}$ & $70 \mathrm{~cm}$ & $85 \mathrm{~cm}$ & $75 \mathrm{~cm}$ & $80 \mathrm{~cm}$ \\
\hline 6. & Permukaan Batang & Kasar & Halus & Kasar & Halus & Kasar \\
\hline 7. & Pertumbuhan Cabang & Beraturan & Rapat & Tidak Beraturan & Beraturan & $\begin{array}{l}\text { Tidak } \\
\text { Beraturan }\end{array}$ \\
\hline 8. & Akar Banir & Tidak & YA & Tidak & Ya & Ya \\
\hline 9. & Diameter Tajuk & $706 \mathrm{~cm}$ & $560 \mathrm{~cm}$ & $620 \mathrm{~cm}$ & $942 \mathrm{~cm}$ & $834 \mathrm{~cm}$ \\
\hline 10. & Bentuk Tajuk & Bulat & Jorong & Lonjong & Bulat & Bulat \\
\hline 11. & Pertumbuhan Pohon & Keatas & Kesamping & Keatas & Keatas & Keatas \\
\hline 12. & Kerapatan Cabang & Jarang & Jarang & Rapat & Jarang & Jarang \\
\hline 13. & Warna Batang & $\begin{array}{l}\text { Coklat } \\
\text { Keputihan }\end{array}$ & Coklat & $\begin{array}{l}\text { Coklat } \\
\text { Keputihan }\end{array}$ & $\begin{array}{l}\text { Coklat } \\
\text { Keputihan }\end{array}$ & Coklat \\
\hline
\end{tabular}

Gambar 1. Variasi Keragaman Morfologi batang durian di desa Sukajadi Makmur; a. batang tembaga, b. batang montong, c. batang Jantung, d. batang kertas dan e. batang musang king. 


\section{Keanekaragaman Morfologi Daun Durian (Durio zubethinus Murr.) di desa Sukajadi Makmur}

Berdasarkan hasil identifikasi terhadap karakteristik daun menunjukan bahwa terdapat bentuk helaian daun yang di temukan di desa Sukajadi Makmur yaitu lonjong, bulat dan sedikit oval (gambar 2). Daun Durian secara umum berbentuk bulat panjang, warna daun hijau terang, hijau tua, hijau keemasan dan hijau gelap.
Menurut penelitian Setiawan (2015) mengemukaan bahwa daun durian umunya berbentuk bulat memanjang (oblongus) dengan bagian ujung yang meruncing, letakknya sendiri berselang-seling dan pertumbuhannya secara tunggal setelah itu struktur daun agak tebal dengan permukaan daun sebelah atas berwarna hiaju mengkilap dan bagian bawah berwarna coklat atau kuning keemasan. Hasil Pengamatan terhadap visual daun durian di tunjukkan pada tabel 2 dan gambar 2 .

Tabel 2. Variasi Morfologi Daun Durian di Desa Sukajadi Makmur

\begin{tabular}{|c|c|c|c|c|c|c|}
\hline No & Karakter & Tembaga & Montong & Jantung & kertas & Musang King \\
\hline 1. & $\begin{array}{l}\text { Warna Permukaan atas } \\
\text { daun }\end{array}$ & Hijau Muda & Hijau Muda & Hijau Tua & Hijau Cerah & Hijau Tua \\
\hline 2. & Warna Permukaan & Hijau & Hijau & Hijau & Hijau & Hijau \\
\hline & Bawah Daun & Keemasan & Keemasan & Keperakan & Keemasan & Keemasan \\
\hline 3. & Kerapatan Daun & Rapat & Sangat Rapat & Kurang Rapat & Rapat & Rapat \\
\hline 4. & $\begin{array}{l}\text { Duduk Daun Pada } \\
\text { Batang }\end{array}$ & Petiolata & Petiolata & Petiolata & Petiolata & Petiolata \\
\hline 5. & Arah Tumbuh Daun & Kedalam & Kedalam & Keluar & Kedalam & Kedalam \\
\hline 6. & $\begin{array}{l}\text { Panjang Tangkai Daun } \\
(\mathrm{mm})\end{array}$ & $18,2 \mathrm{~mm}$ & $17,6 \mathrm{~mm}$ & $12,8 \mathrm{~mm}$ & $12,2 \mathrm{~mm}$ & $12,6 \mathrm{~mm}$ \\
\hline 7. & Kondisi Tangkai Daun & Datar & Membulat & $\begin{array}{l}\text { Setengah } \\
\text { lingkaran }\end{array}$ & Membukat & Datar \\
\hline 8. & $\begin{array}{l}\text { Panjang Tangkai Daun } \\
(\mathrm{cm})\end{array}$ & $16,5 \mathrm{~cm}$ & $14,2 \mathrm{~cm}$ & $15,3 \mathrm{~cm}$ & $11,1 \mathrm{~cm}$ & $13,6 \mathrm{~cm}$ \\
\hline 10. & Bentuk Helaian Daun & Persegi & Bulat Panjang & Membulat & Bulat Panjang & Bulat Telur \\
\hline 11. & Bentuk Ujung Daun & Runcing & Runcing & Runcing & Meruncing & Tumpul \\
\hline 12. & Bentuk Dasar Daun & Lonjong & Sedikit Oval & Bulat & Bulat & Lonjong \\
\hline 13. & Margin Daun & Berliku & Rata & Rata & Rata & Sedikit Berigi \\
\hline 14. & $\begin{array}{l}\text { Lapisan Lilin pada } \\
\text { permukaan Daun }\end{array}$ & Rambut sisik & Rambut sisik & Rambut sisik & Rambut sisik & Rambut sisik \\
\hline
\end{tabular}

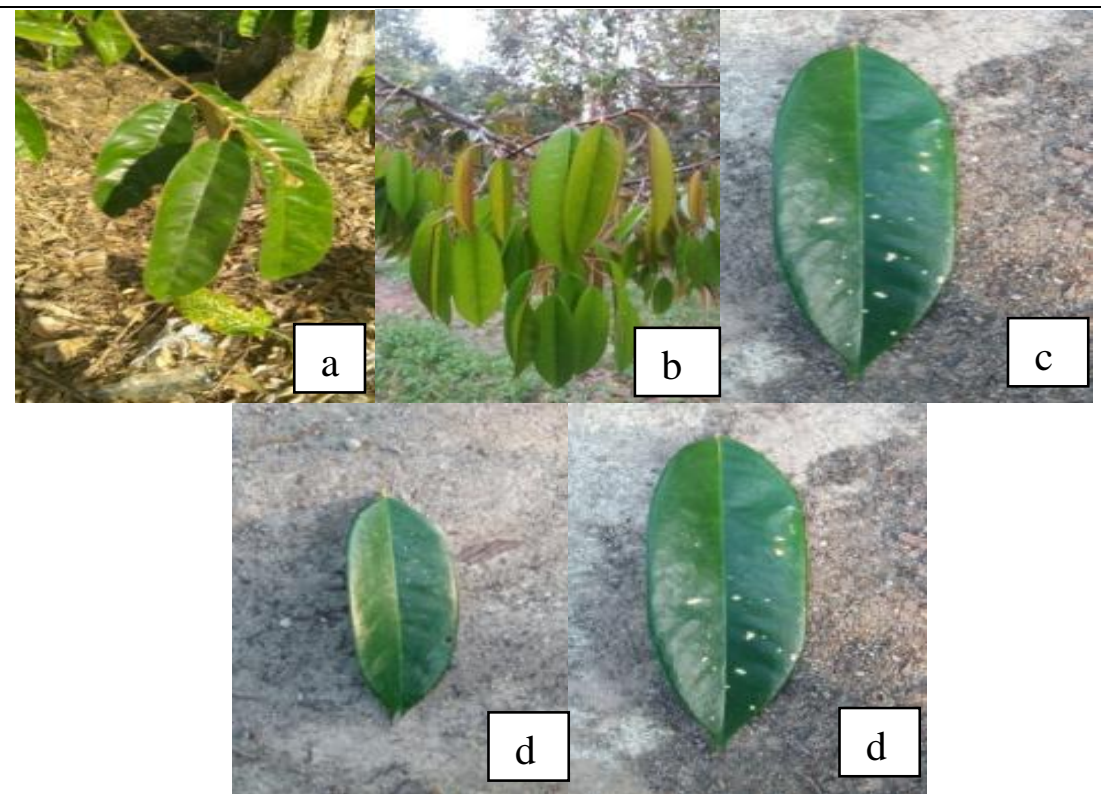

Gambar 2. Variasi Morfologi daun durian di desa Sukajadi Makmur; a. daun tembaga, b. daun montong, c. daun jantung, d. daun kertas, dan e. daun musang king 


\section{Keanekaragaman Morfologi Buah Durian di Desa Sukajadi Makmur}

Berdasarkan hasil penelitian morfologi buah durian pada umumnya bervariasi tergantung dari tempat tumbuhkan tumbuhan bauh durian, dari hasil penelitian ditemukan bahwa terdapat beberapa variasi bentuk buah durian yaitu bulat datar, bulat, bulat telur, lonjong dan bulat panjang (gambar 3).

Secara umum bentuk durian di desa Sukajadi Makmur adalah bulat, oval, dan lonjong. Warna kulit buah yaitu hijau kecoklatan, rasa buah manis, warna gading buah yaitu kuning dan putih dan model pengelompokan 1 buah per kelompok dengan ukuran yang bervariasi. Hal ini sesuai dengan litelatur Tirtawinata et al., (2016) yang mengemukakan bahwa durian merupakan organ yang paling bervariasi mulai dari bulat, oval, lonjong, berbelimbing, jantung, sampai tidak beraturan. Warna kulit buah umumnya hijaucoklat, buah durian juga bervariasi pada ukuran dan bobot buah. Hasil Pengamatan terhadap visual buah durian di tunjukkan pada tabel 3 dan gambar 3 .

Tabel 3. Variasi Morfologi Buah Durian di Desa Sukajadi Makmur

\begin{tabular}{|c|c|c|c|c|c|c|}
\hline No & Karakter & Tembaga & Montong & Jantung & Kertas & Musang king \\
\hline 1. & Bentuk Buah & $\begin{array}{l}\text { Bulat } \\
\text { Sempurna }\end{array}$ & $\begin{array}{l}\text { Lonjong } \\
\text { Memanjang }\end{array}$ & Jantung & Membulat & Lonjong \\
\hline 2. & Bentuk Ujung Buah & Lonjong & Runcing & Runcing & Membulat & Runcing \\
\hline 3. & Bentuk Dasar Buah & Bulat & Lonjong & Jantung & Bulat & Lonjong \\
\hline 4. & $\begin{array}{l}\text { Panjang Tangkai Buah } \\
(\mathrm{cm})\end{array}$ & $2 \mathrm{~cm}$ & $3 \mathrm{~cm}$ & $2,5 \mathrm{~cm}$ & $2 \mathrm{~cm}$ & $2 \mathrm{~cm}$ \\
\hline 5. & $\begin{array}{l}\text { Kekuatan Perlekatan } \\
\text { Tangkai Buah }\end{array}$ & Cukup Kuat & Sangat Kuat & Cukup Kuat & Kuat & Cukup Kuat \\
\hline 6. & Warna Tangkai Buah & Coklat Gelap & Coklat Gelap & Coklat & Coklat Terang & Coklat Gelap \\
\hline 7. & Bentuk Duri Buah & Segitiga & Kerucut & Lonjong & Segitiga & Piramida \\
\hline 8. & Duri Buah & Besar & Sedang & Besar & Kecil & Sedang \\
\hline 9. & Permukaan Duri Buah & Halus & Halus & Kasar & Halus & Kasar \\
\hline 10. & Kerapatan Duri Buah & Cukup Rapat & Rapat & Rapat & Sangat Rapat & Kurang Rapat \\
\hline 11. & Panjang Duri Buah & $1 \mathrm{~cm}$ & $1 \mathrm{~cm}$ & $1 \mathrm{~cm}$ & $1 \mathrm{~cm}$ & $1,5 \mathrm{~cm}$ \\
\hline 12. & Diameter Buah & $20 \mathrm{~cm}$ & $25 \mathrm{~cm}$ & $2 \mathrm{~m}$ & $15 \mathrm{~cm}$ & $2 \mathrm{~m}$ \\
\hline 13. & Berat Buah (Kg) & $5 \mathrm{~kg}$ & $3-6 \mathrm{~kg}$ & $2-5 \mathrm{~kg}$ & $2-4 \mathrm{~kg}$ & $4 \mathrm{~kg}$ \\
\hline 14. & Ketebalan Kulit Buah & $3 \mathrm{~cm}$ & $4-6 \mathrm{~cm}$ & $3 \mathrm{~cm}$ & $3 \mathrm{~cm}$ & $3 \mathrm{~cm}$ \\
\hline 15. & Warna Kulit Buah & Hijau & Kuning & $\begin{array}{l}\text { Hijau } \\
\text { Kekuningan }\end{array}$ & $\begin{array}{l}\text { Kuning } \\
\text { Kecokalatan }\end{array}$ & Hjiau Semu \\
\hline 16. & Ketebalan Aril Buah & Sangat tebal & Cukup Tebal & Tebal & Cukup Tebal & Tebal \\
\hline 17. & Tekstur Aril Buah & Lembut & Lembut & Cukup Lembut & Lembut & Lembut \\
\hline 18. & Rasa Buah Segar & Sangat Manis & Manis Legit & Manis & Cukup Manis & $\begin{array}{l}\text { Manis sedikit } \\
\text { Pahit }\end{array}$ \\
\hline 19. & Aroma Buah Segar & Sangat Harum & Harum Tajam & Harum & Cukup Harum & Sangat Harum \\
\hline 20. & Warna Buah Segar & Kuning Pekat & Kuning & Kuning & Putih & Kuning \\
\hline 21. & Jumlah Biji Per lokus & $2-3$ & $3-5$ & 3 & 3 & 3 \\
\hline 22. & Panjang Biji (cm) & $4 \mathrm{~cm}$ & $3 \mathrm{~cm}$ & $2 \mathrm{~cm}$ & $2 \mathrm{~cm}$ & $3-4 \mathrm{~cm}$ \\
\hline 23. & Lebar Biji (cm) & $3 \mathrm{~cm}$ & $2 \mathrm{~cm}$ & $3 \mathrm{~cm}$ & $2,5 \mathrm{~cm}$ & $3,5 \mathrm{~cm}$ \\
\hline 24. & Bentuk Biji & Oval & Lonjong & Lonjong & Bulat & Lonjong \\
\hline 25. & Warna Kulit Biji & Kekuningan & $\begin{array}{l}\text { Kuning } \\
\text { Kecoklatan }\end{array}$ & Kekuningan & Putih Kusam & Kekuningan \\
\hline
\end{tabular}




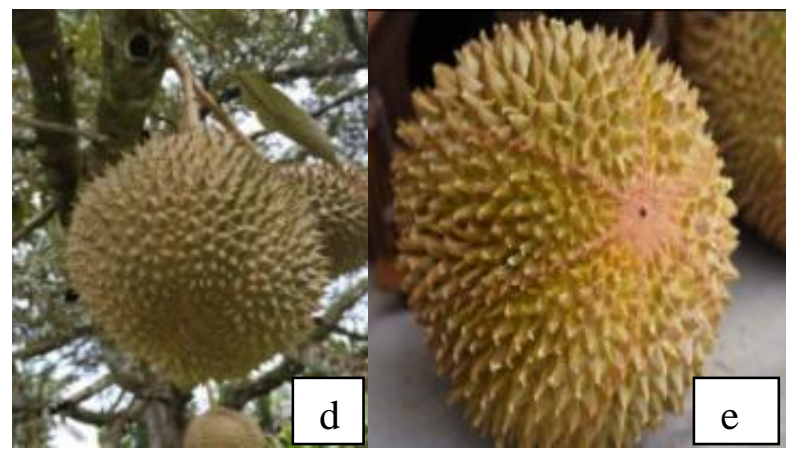

Gambar 3. Variasi Morfologi buah durian di desa Sukajadi Makmur; a. durian tembaga, b. durian montong, c. durian jantung, d. durian kertas, dan durian musang king.

\section{Potensi Ekonomi Durian di Desa Sukajadi Makmur}

Jenis durian yang dikembangan oleh masyarakat desa Sukajadi Makmur merupakan durian lokal yang sudah ada sejak nenek moyang sehingga merupakan hasil dari turun-temurun dan dibudidayakan dengan cara yang masih tradisional. Tidak ada perawatan Khusus yang diberlakukan oleh masyarakat setempat terhadap tanaman durian yang dimiliki, karena kondisi lingkungan sudah sangat mendukung pertumbuhan tumbuhan durian. Potensial ekonomi masyarakat pada pemasaran durian berdasarkan kepemilikan tanaman durian pada musim panen terdapat pada Tabel 4. Dan rekapitulasi masyarakat desa Sukajadi Makmur pada Tabel 5.

Tabel 4. Jumlah Pemasaran Petani Durian Desa Sukajadi Makmur

\begin{tabular}{|c|c|c|c|c|}
\hline \multirow[b]{2}{*}{ Nama Kultivar } & \multirow[b]{2}{*}{$\begin{array}{c}\text { Bagian Yang } \\
\text { Dijual }\end{array}$} & \multicolumn{3}{|c|}{ Pemasaran } \\
\hline & & $\begin{array}{c}\text { Jumlah Rumah } \\
\text { Tangga }\end{array}$ & $\begin{array}{c}\text { Kuantitas Rata- } \\
\text { Rata (Buah) }\end{array}$ & Harga (Rp/Buah) \\
\hline Tembaga & Buah & 24 & 52 & 35.000 \\
\hline Montong & Buah & 15 & 30 & 30.000 \\
\hline Jantung & Buah & 48 & 65 & 40.000 \\
\hline Kertas & Buah & 10 & 24 & 20.000 \\
\hline Musang King & Buah & 50 & 82 & 45.000 \\
\hline \multicolumn{2}{|c|}{ Total } & 147 & 251 & 170.000 \\
\hline
\end{tabular}

Masyarakat desa Sukajadi Makmur bekerja tetap sebagai petani karet dengan peghasilan $6.000 / \mathrm{kg}$ dari getah karet yang dikumpulkan dalam jangka waktu 3 hari/pohon, biasanya petani karet rata-rata dapat mengumpulkan 160/kg dalam satu bulan dari banyaknya pohon maka pendapatan masyarakat desa Sukajadi Makmur perbulan adalah $160 / \mathrm{kg} \times 6.000 / \mathrm{kg}=\mathrm{Rp}$. 960.000/bulan dengan total rata-rata pertahun adalah $\mathrm{Rp}$. 960.000/bulan x 12 bulan = Rp. 11.520.000.- disetiap tahunnya. Bekerja sebagai petani durian hanyalah terjadi saat musim durian tiba, Durian yang dijual dilakukan perbuah bukan perkilogram, dan rata-rata pendapatan petani durian dalam menjual durian dalam pertahun adalah Rp. 170.000/buah x 12 bulan = Rp. 2.040.000 dipertahunnya.

Tabel 5. Rekapitulasi Jumlah Masyarakat Desa Sukajadi Makmur

\begin{tabular}{|c|c|c|c|c|c|}
\hline \multirow[t]{2}{*}{ No } & \multirow[t]{2}{*}{ Nama Dusun } & \multirow{2}{*}{$\begin{array}{c}\text { Jumlah } \\
\text { Kepala } \\
\text { Keluarga }\end{array}$} & \multicolumn{2}{|c|}{$\begin{array}{c}\text { Jumlah Penduduk Menurut } \\
\text { Jenis Kelamin }\end{array}$} & \multirow{2}{*}{$\begin{array}{c}\text { Jumlah } \\
\text { Penduduk }\end{array}$} \\
\hline & & & Laki - Laki & Perempuan & \\
\hline 1. & Alur Buaya & 71 & 169 & 124 & 289 \\
\hline 2. & Trom & 41 & 69 & 71 & 140 \\
\hline 3. & Loh & 63 & 121 & 119 & 240 \\
\hline & Total & 175 & 355 & 314 & 669 \\
\hline
\end{tabular}

Sumber: Data Sekunder, Desa Sukajadi Makmur Desember 2019 
Perbandingan Pendapatan desa Sukajadi Makmur dengan daerah lainnya sangat jauh berbeda. Durian Medan menggunakan strategi memposisikan produk melalui harga dan kualitas. Durian Medan menetapkan harga durian yang berkisaran antara Rp. 50.000.- sampai Rp. 150.000.- tergantung dengan rasa dan ukuran dari buah durian. Buah yang ukurannya kecil dengan harga Rp. 50.000.- ukuran sedang harga buah ukuran sedang Rp. 100.000.- dan untuk ukuran besar dengan harga Rp. 150.000.- tersedia juga paket durian kemasaran dari harga Rp. 100.000.- s.d Rp. 500.000.-. Maka pendapatan yang dihasilkan oleh petani durian medan adalah $\mathrm{Rp}$. $50.000+$ Rp. $100.000+$ Rp. $150.000=$ Rp. 300.000. $-\mathrm{x}$ 12 bulan = 3.600.000.- pertahunnya. Tetapi, harga tersebut dapat berubah apabila sedang mengalami musim durian akan lebih murah dan jika tidak musim durian harga akan semakin mahal (Imsar, 2018).

Saluran pemasaran durian dari petani ke konsumen akhir melibatkan beberapa lembaga pemasaran, yaitu petani, pedagang pengumpul dan pedagang pengecer. Panjang pendeknya saluran pemasaran suatu barang ditandai dengan banyaknya lembaga pemasaran yang dilalui oleh barang tersebut mulai dari produsen hingga konsumen akhir (Qurniati, 2010). Saluran Pemasaran yyang paling efesien dapat dilihat dari panjang dan pendeknya kegiatan pemasaran barang, jika semakin panjang rantai pemasarannya maka semakin tidak efisien (Putri et al., 2014). Berikut saluran rantai penjualan durian di desa Sukajadi Makmur dengan fungsi petukaran.

Saluran pertama dilakukan oleh petani durian dari fungsi petukaran berupa kegiatan penjualan dari petani yang juga bertindak sebagai pedagang pengecer dengan langsung menjual duriannya ke konsumen akhir dipasar.

Saluran Kedua petani melakukan penjualan durian dengan sistem sewa semalam, dimana fugsi petukaran berperan dalam sewa semalam dengan cara konsumen datang langsung ke lahan garapan petani durian untuk menunggu durian yang jatuh selama semalam tersebut.

Saluran Ketiga Petani durian melakukan fungsi petukaran dengan pembelian dari pedagang pengecer yang membeli langsung ke petani durian yang dilakukan dikebun atau dirumah petani.

Saluran keempat petani melakukan fungsi petukaran dengan cara pembelian dari petani ke pedagang pengumpul dengan membeli borongan lalu, menjual kepada pedagang pengecer. sistem pembelian dengan cara borongan sangat merugikan petani, jumlah durian yang dihitung dipohon jauh lebih sedikit dari pada jumlah yang dipanen oleh pemborong (Quarniati., 2002). Sehingga pedagang pengumpul lebih banyak memperoleh keuntungan dari jumlah durian yang diborong. Namun, pembelian dengan sistem borongan hanya dilakukan jika hasi panen melimpah (Wulandari, D. et al., 2018).

Rantai penjualan durian sangatlah panjang, dikarenakan berdasarkan hasil penelitian menunjukan bahwa informasi hanga hanya diperoleh dari sesame petani dan sesame pedagang atau dengan melihat harga durian dipasar (Wulandari, D. et al., 2018).

Cara yang tepat untuk memangkas saluran pemasaran yang dilakukan petani durian adalah mendapatkan informasi detail mengenai harga durian berdasarkan kualitas dan rasa dari buah durian sebelum melakukan proses jual-beli, sehingga dapat mendatangkan keuntungan bagi petani durian.

\section{Kesimpulan}

Telah ditemukan sebanyak lima kultivar durian di desa Sukajadi Makmur. Karakter kultivar morfologi durian ditemukan sangat beragam baik dari morfologi batang, daun, maupun buah. Hasil karakterisasi morfologi untuk bentuk pohon durian (Jorong, Bulat, dan Lonjong), Permukaan batang (kasar dan halus), Bentuk daun (lonjong, empat persegi, bulat panjang dan bulat telur) dan bentuk buah (Bulat, membulat, bulat telur, lonjong dan bulat panjang). Perlu dilakukan penelitian secara khusus yang mengarahkan pada eksplorasi karakteristik sifat morfologi dan molekuler serta kualitas buah durian dari Provinsi Aceh.

\section{Ucapan terima kasih}

Penulis mengucapkan terimakasih kepada seluruh masyarakat desa Sukajadi Makmur yang telah membantu pelaksanaan penelitian ini. Penelitian ini bersumber dari pendanaan mandiri.

\section{Daftar Pustaka}

Baroroh, Nasri, Fitmawati \& Neri, S. (2014). Analisis Hubungan Kekerabatan Durian (Durio zibethinus Murr.) Bedasarkan Penanda Morfologi di Kabupaten Kuantan Singingi. JOM FMIPA. Vol.1 No.2. https://jom.unri.ac.id/index.php/JOMFMIPA/artik el/view/4056

Belgis, M., Wijaya, C.H., Apryantono, A., Kusbiantoro, B. \& Yuliana, N.D. (2016). Physicochemical Differences and Sensory Profiling Of Six Lai (Durio kutejensis) dan FourDurian (Durio zibethinus) Cultivars indigenous Indonesia. Internasional Food Research Jurnal. No. 23(4). 
http://www.ifrj.upm.edu.my/23\%20(04)\%202016 /(17).pdf

Bioversity. (2007). Descriptors For Durian (Durio zibethinus Murr.) Rome, Italy: Bioversity Internasional.

https://www.bioversityinternasional.org/uploads/t $\mathrm{X}$ _news/Descriptors for durian_Durio_zibethinus Murr. 1260.pdf

Dang, T.N. \& Nguyen B. H. (2015). Study On Durian Processing Technology and Defleshing Machine. Asia Pacific Jurnal Of Sustainable Agriculture, Food and Energy. No. 3(1). Hal 12-16. https://journal.bakrie.ac.id/index.php/APJSAFE/a $\underline{\text { rticle/view/886 }}$

Handayani, R.S. \& Ismadi (2017). Analisis Keragaman Buah Durian Unggulan (Durio zibethinus) Aceh Timur. J Hort Indonesia, 8(3): 147-154. https://journal.idp.ac.id/index.php/jhi/artticle/dow $\underline{\text { nload/20137/13894/ }}$

Navia, Z. I., Suwardi, A. B. \& Saputri, A. (2017). Penelusuran ragam jenis tanaman buah pekarangan sebagai sumber nutrisi bagi masyarakat di Kota Langsa, Aceh. In Dalam: Agustien, A., Syaifullah, Pitopang, RP, Nurainas, Ilyas, S. \& Kurniawan, R.(editor) Prosiding Seminar Nasional Biodiversitas dan Ekologi Tropika Indonesia Ke-4 dan Kongres Penggalang Taksonomi Tumbuhan Indonesia Ke-12. Padang (pp. 15-17). https://www.researchgate.net/publication/324137 183 PENELUSURAN_RAGAM JENIS TANA MAN BUAH PEKARANGAN_SEBAGAI SU MBER_NUTRISI_BAGI_MASYARAKAT_DI KOTA_LANGSA_ACEH

Navia, Z. I., Suwardi, A. B. \& Saputri, A. (2019). Karakterisasi Tanaman Buah Lokal di Kawasan Ekosistem Leuser Kabupaten Aceh Tamiang, Aceh. Buletin Plasma Nutfah, 25(2), 57-66. https://doi.org/10.21082/blpn.v25n2.2019.p57-66

Pratiwi, N., Diana, S.H. \& Lutfi A.M.S. (2018). Identifikasi Karakter Morfologi Durian (Durio zibethinus Murr.) di Kecamatan Tigalingga dan Pegagan Hilir Kabupaten Dairi Sumatra Utara. Jurnal Agroekoteknologi. Vol. $6 . \quad$ No.2. https://jurnal.usu.ac.id/index.php/agroekoteknolo gi/article/download/17271/9190

Salasa, N.K., Arum, N. \& Herlina. (2013). Identifikasi Tanaman Durian (Durio zibethinus Murray)
Mirip Dengan Varietas Bido di Kecamatan Wono Salam Kabupaten Jombang Dengan Metode Isozim dan Morfologi. Jurnal Produksi Tanaman. 1(5): 427-433. https://protan.studentjournal.ub.ac.id/index.php/pr otan/article/view/54

Somsri, S. (2017). Production, Diversity and Utilization Of Durian In Thailland. In Acta Horticulturae. Vol 1186:1-13. https://www.actahort.org/members/showpdf?book $\underline{\text { nrarnr}=1186 \_1}$

Sunaryo, W., Hendra, M., Rudarmono, Suprapto, H., Pratama, A.N. \& Rahman. (2015). Ekploration and Identification Of Lai Durian, New Highly Economic Potential Cultivars Derived From Natural Crossing Between Durio zibethinus and Durio kutejensis In East Kalimantan. Asian Journal Of Microbiology, Biotekhnology and Environmental Sciences.17(2): 365-371. https://www.researchgate.net/publication/280632 538 Ekploration_and_Identification_Of_Lai_Dur ian_new highly economic potential_cultivars d erived_from natural_crossing between_durio_zi bethinus and Durio_kutejensis in East_Kaliman $\underline{\tan }$

Suwardi, A.B., Indriaty \& Navia, Z.I. (2018). Nutritional Evaluation of Some Wild Edible Tuberous Plants as an Alternative Foods. Innovare Journal Of Food Sci 6(2), 9-12. https://www.researchgate.net/publication/328381 307 NUTRITIONAL_EVALUATION_OF_SO ME WILD EDIBLE TUBEROUS PLANTS A S_AN_ALTERNATIVE_FOODS

Suwardi, A. B., Navia, Z. I., Harmawan, T., Syamsuardi \& Mukhtar, E. (2019a). The Diversity of Wild Edible Fruit Plants And Traditional Knowledge In West Aceh Region, Indonesia. Jurnal of Medicinal Plants, 7(4), 285-290. http://www.plantsjournal.com/archives/?year=201 9\&vol=7\&issue $=4 \&$ part $=$ D\&ArticleId $=1040$

Suwardi, A. B., Navia, Z. I., Harmawan, T., Syamsuardi \& Mukhtar, E. (2019b). Sensory Evaluation of Mangoes Grown in Aceh Tamiang District, Aceh, Indonesia. Advances in Ecological and Environmental Research 4 (3), 79-85. https://www.researchgate.net/publication/332104 711_Sensory_Evaluation_of_Mangoes_Grown_in Aceh_Tamiang_District_Aceh_Indonesia 
Suwardi, A.B., Navia, Z.I., Harmawan, T., Samsuardi \& Mukhtar, E. (2020a). Ethnobotany and Conservation Of Indigenous Edible Friut Plants In South Aceh, Indonesia. BIODIVERSITAS 21(5); 1850-1860. https://smujo.id/biodiv/article/view/4810

Suwardi, A.B., Navia, Z.I., Harmawan, T., Samsuardi \& Mukhtar, E. (2020b). Ethnobotany, Nutritional Composition and Sensory of Garcinia From Aceh, Indonesia. Materials Science and Engineering 725(1): 012064. https://iopscience.iop.org/article/10.1088/1757$\underline{899 X / 725 / 1 / 0120064}$

Wulandari, D., Rommy, Q. \& Susni H. (2018). Efisiensi Pemasaran Durian (Durio Zubthinus) di Desa Wisata Durian Kelurahan Sumber Agung. Jurnal $\begin{array}{llll}\text { Sylva Lestari. } & \text { Vol.6 }\end{array}$
https://repository.lppm.unila.ac.id/9335/1/DITA\% 20WULANDARI.pdf

Yuniastuti, E., Anggita, A., Nandariyah \& Sukaya. (2018). Local Durian (Durio zibethinus Murr.) Eksploration For Potentially Superior Tree as Parents In Ngrambe District, Ngawi. In IOP Conference Series: Earth and Environmental Science. $\quad$ Vol. 012029. https://iopscience.iop.org/article/10.1088/17551315/142/1/012029

Yuniastuti, E., Nandariyah \& Samuel R.B. (2018). Karakterisasi Durian (Durio zibethinus) Ngrambe di Jawa Timur, Indonesia. CarakaTani: Journal of Sustainable Agriculture. 33(2):136-145. https://www.researchgate.net/publication/328350 432_Karakterisasi_Durian_Durio_zibethinus_Ngr ambe_di Jawa Timur_Indonesia 